\title{
Corrigendum
}

\section{Corrigendum to "Ecofriendly Synthesis of Silver Nanoparticles from Garden Rhubarb (Rheum rhabarbarum)"}

\author{
P. R. Reddy, S. D. Ganesh, N. Saha, O. Zandraa, and P. Sáha \\ Centre of Polymer Systems, University Institute, Tomas Bata University in Zlin, Tř. T. Bati 5678, 76001 Zlin, Czech Republic \\ Correspondence should be addressed to N. Saha; nabanita@ft.utb.cz
}

Received 14 December 2016; Accepted 26 December 2016; Published 9 March 2017

Copyright (C) 2017 P. R. Reddy et al. This is an open access article distributed under the Creative Commons Attribution License, which permits unrestricted use, distribution, and reproduction in any medium, provided the original work is properly cited.

In the article titled "Ecofriendly Synthesis of Silver Nanoparticles from Garden Rhubarb (Rheum rhabarbarum)" [1],

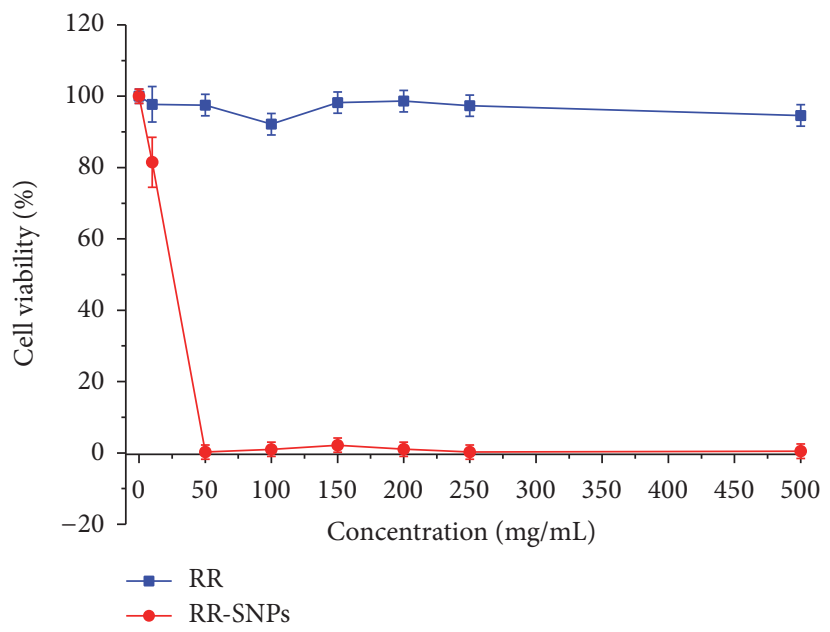

(a) the legend of Figure 6 should be corrected as follows.

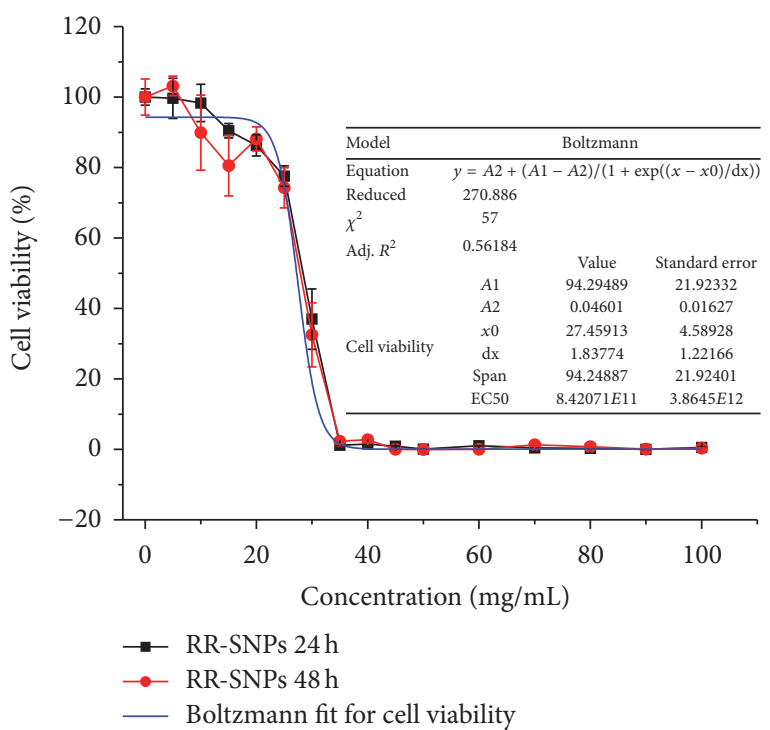

(b)

FIGURE 6: Anticancer activity of (a) RR and RR-SNPs on HeLa cell lines after $24 \mathrm{~h}$ of incubation and (b) RR-SNPs on HeLa cell lines after $24 \mathrm{~h}$ and $48 \mathrm{~h}$ of incubation. These experiments were conducted at the Polymer Institute, Slovak Academy of Science, Bratislava.

\section{References}

[1] P. R. Reddy, S. D. Ganesh, N. Saha, O. Zandraa, and P. Sáha, "Ecofriendly synthesis of silver nanoparticles from garden rhubarb (Rheum rhabarbarum)," Journal of Nanotechnology, vol. 2016, Article ID 4964752, 9 pages, 2016. 

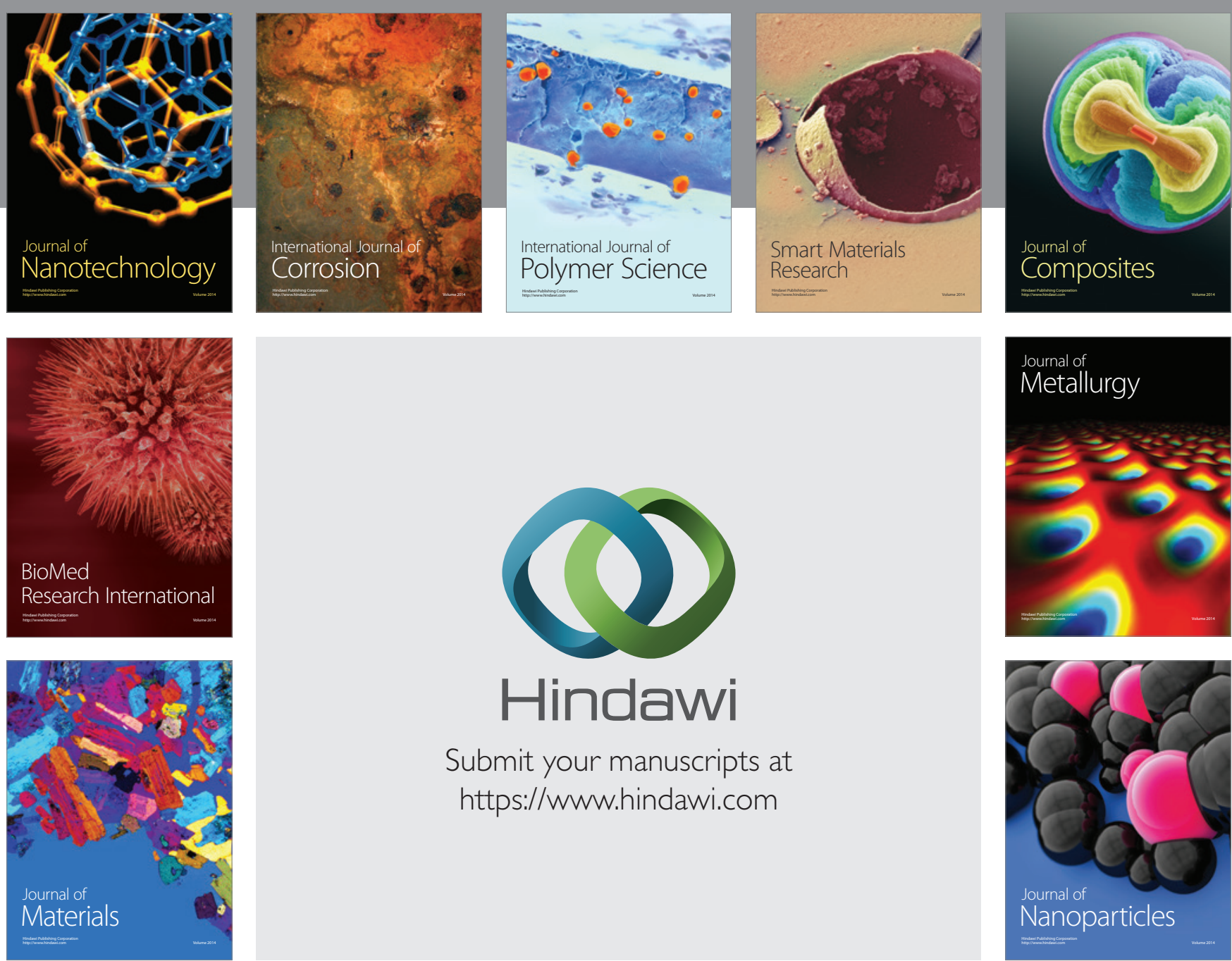

\section{Hindawi}

Submit your manuscripts at

https://www.hindawi.com

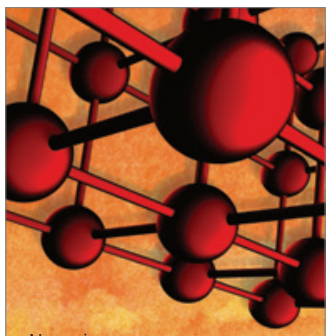

Materials Science and Engineering
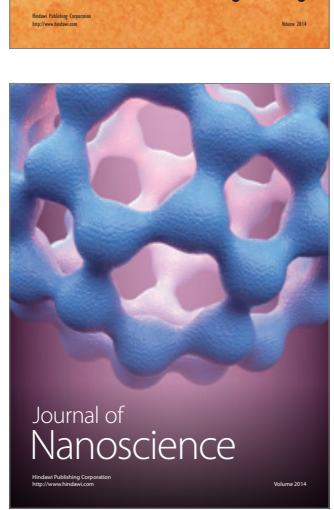
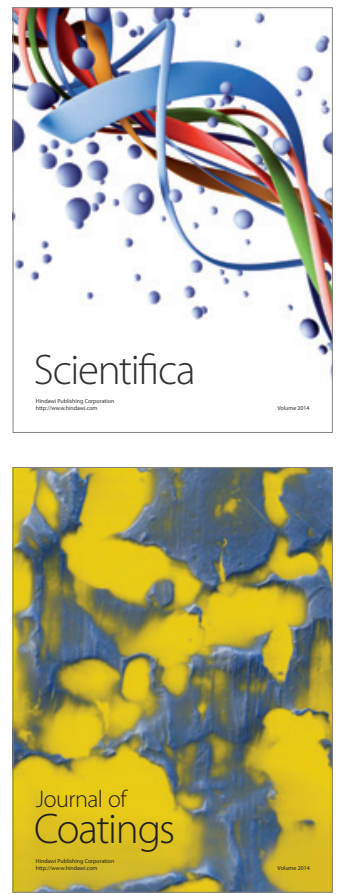
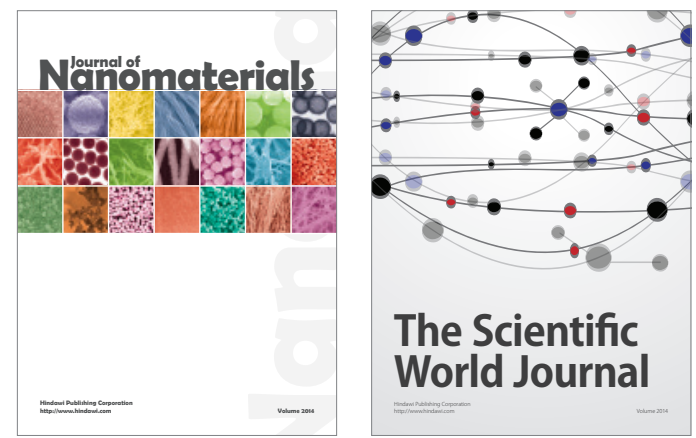

The Scientific World Journal
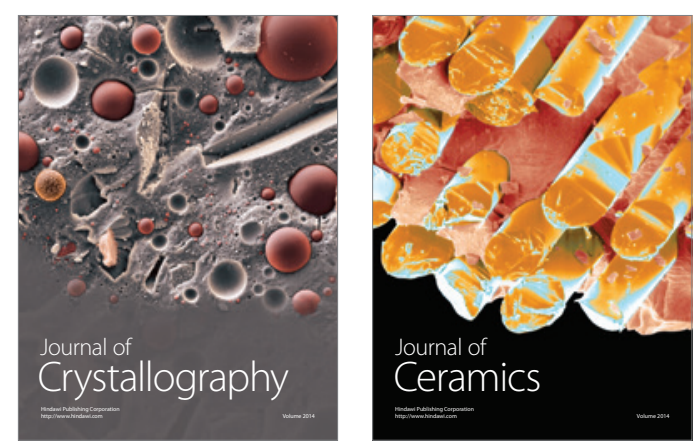
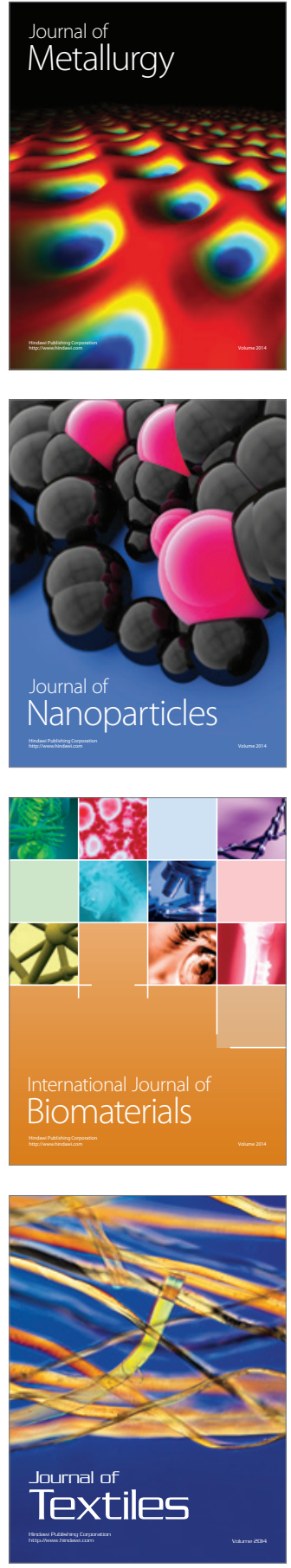